\title{
BOTANICAL STUDY OF FICUS AURICULATA LOUR.
}

\author{
Ahlam M. El-Fishawy ${ }^{1}$, Rawia A. Zayed ${ }^{2,3}$, Sherif M. Afifi ${ }^{2 *}$ \\ ${ }^{1}$ Dept. of Pharmacognosy, Faculty of Pharmacy, Cairo University, Cairo, Egypt. \\ ${ }^{2}$ Dept. of Pharmacognosy, Faculty of Pharmacy, Sinai University, North Sinai, Egypt. \\ ${ }^{3}$ Dept. of Pharmacognosy, Faculty of Pharmacy, Zagazig University, Zagazig, Egypt.
}

\begin{abstract}
The macro- and micromorphological characters of the stem, leaf and fruit of Ficus auriculata Lour. (Family Moraceae) cultivated in Egypt have been studied in order to find out the diagnostic features of these organs which can help in their identification in both entire and powdered forms. This study is considered as a method to check the genuineness of the raw drugs.
\end{abstract}

Keywords: Moraceae; Ficus auriculata; botanical.

\section{INTRODUCTION}

Moraceae consists of trees, shrubs, climbers and few herbs distributed in tropical, subtropical and temperate regions. Most produce a milky latex sap. Fruits are composite. Some trees have adventitious aerial or adhering roots (Llamas, 2003).

Moraceae constitutes fifty genera and nearly 1500 species, including some important groups like Artocarpus, Morus and Ficus (Ventakamaran, 1972).

Members of genus ficus are characterized by their physiological and medicinal values such as antioxidant (Channabasavaraj, et al., 2008; Oliveira; et al., 2009; Verma, et al., 2010), antihepatotoxic (Channabasavaraj, et al., 2008), antimicrobial (Kuete, et al., 2008; Chen, et al., 2010; Subramaniam, et al.,2009), anticancer (Chiang, et al., 2010; Khan and Sultana, 2005; ), antidiabetic (Pandit, et al., 2010), antipyretic (Bafor, et al., 2010) and antiinflammatory (Mandal, et al., 2000).

Ficus auriculata Lour. is an evergreen tree reaching 4-10m in height, crown elongated and wide. Bark is grayish brown and rough. Branchlets are reddish brown, 1-1.5 cm thick and leafless in middle of stem. Leaves are alternate, broadly ovate-cordate, having shallowly dentateentire margin and obtuse-mucronate apex. Figs are (syconus fruits) pear-like shaped, with 8-12 conspicuous longitudinal ridges. Male flowers are minute, sessile; with 3 lobes calyx, transparent, spatulate, thinly membranous; with 2 stamens; long filaments and ovoid anthers. Female flowers are minute, pedicellate or sessile; with 3 lobes calyx and ovoid ovary (Zhekun and Gilbert, 2003; Bailey 1958; Saber, 1966).

Ficus auriculata Lour. the plant under investigation has been cited in the old literature for its medicinal properties. The juice of this plant was used in diarrhea (Bhattarai, 1993). In India, the fresh latex was used to treat dental caries (Jain and Puri, 1984). Our previous publication dealt with isolation and identification of flavonoids, coumarins, triterpens, sterols and the biological investigation of the alcoholic extracts of leaves and fruits (El-Fishawy, et al., 2011).

Reviewing the available current literature, nothing was reported concerning the botanical studies of Ficus auriculata Lour. It was interesting to study the macro- and micromorphological characters of the stem, leaf and fruit. 


\section{EXPERIMENTAL}

\subsection{Plant material:}

Samples of Ficus auriculata were collected in the fruiting stage (October 2008) from the plant cultivated in Orman Garden, Giza, Egypt, identified by Mrs. Trease Labib, consultant of plant taxonomy at the Ministry of Agriculture and former director of Orman Garden. Identification was further kindly confirmed by Prof. Dr. M. El-Gebally, botanist specialist. Voucher specimen (no. 0121030) was kept in the Department of Pharmacognosy, Faculty of Pharmacy, Cairo University.

Fresh samples preserved in alcohol $70 \%$ containing glycerol 5\% were used for botanical study. The fresh samples were fixed for at least $48 \mathrm{hrs}$ in Formalin- acetic acid- $70 \%$ alcohol (5: 5: 90) and dehydrated, paraffin infiltrated and embedded in wax using customary techniques (Johansen, 1940; Sass, 1940). Transverse sections which were cut on a rotary microtome to a thickness of 15 microns were stained with safranin and fast green. A light microscope was used to view the slides. Microphotographs were obtained using a Nikkon digital camera focused through the microscope eyepiece.

\subsection{Botanical study of Ficus auriculata Lour.}

\subsubsection{Macrmorphology: (Fig. 1A-G):}

Ficus auriculata Lour. is an evergreen tree, reaching about $9 \mathrm{~m}$ in height (Fig. 1A). It is grown without aerial roots. The trunk is about $4 \mathrm{~m}$ in length, grayish brown and rough. The trunk and other parts of the tree exude thick white latex by incision.

\subsubsection{The young stem: (Fig. 1B):}

Young branches are green in colour, cylindrical, hairy; measure $0.6-1.2 \mathrm{~cm}$ in diameter, showing nodes and internodes measuring about $0.6-2.5 \mathrm{~cm}$ in length. Branching is monopodial and topped by large bulging buds. The branches have characteristic odour and bitter taste.

\subsubsection{The leaves: (Fig. 1C, D):}

Leaves are simple, cauline, alternate, broadly ovate-cordate having shallowly dentate or entire margin, pubescent along main veins, green in colour, stipulate and petiolate. They are symmetrical, obtuse to mucronate apex and broadly cordate base. Venation pinnate reticulate, the upper surface is darker green than the lower and the midrib is prominent on the lower side. The leaf has a leathery texture. It measures $7-20 \mathrm{~cm}$ in length and $6-14 \mathrm{~cm}$ in width and the petiole measures $3-12 \mathrm{~cm}$. The leaf has faint characteristic odour and bitter taste.

\subsubsection{The fruits: (Fig. 1E-G):}

Fruits are syconus (composite or compound); consisting of a succulent, hollow axis, enclosed within achene-like bodies, formed from numerous minute pistillate flowers lining the axis of inflorescence. Bracts and male flowers are at the upper part around the apical orifice of the fruit (Fig. 1G). The fruits are globose to pear-like shaped with conspicuous longitudinal ridges, aggregated on leafless branches (Fig. 1E). The fruit is silky-hairy, green to reddish brown in colour and measures $5.5-7 \mathrm{~cm}$ in diameter, $2.5 \mathrm{~cm}$ long stalk. The fruit has faint characteristic odour and slightly disagreeable taste.

\subsubsection{Micromorphology:}

\subsubsection{The young stem: (Fig. 2A-G):}

A transverse section in a young stem branch shows an outer epidermis, followed by wide cortex, which is formed of sclerenchymatous, collenchyma and parenchymatous layers. The pericycle is parenchymatous interrupted by small groups of fibers surrounding a complete ring of vascular tissue and central pith (Fig. 2B). 
The Epidermis; consists of polygonal to subrectangular, axially elongated cells with straight anticlinal walls and covered with smooth cuticle (Fig. 2C), showing few sunken anomocytic stomata and trichomes (protruding from the epidermal cells). The trichomes (Fig. 3B) are non-glandular, unicellular either short, thin-walled with acute curved apex or mostly long, thick-walled with narrow lumen, acute apex and covered by smooth cuticle. The cortex; consists of a continuous layer of 2-3 rows of polygonal, isodiametric to slightly elongated with straight to wavy thick-walled lignified sclereids (Fig. 2D, 3G), a collenchymatous layer in 7-10 rows and a parenchymatous layer comprising 13-22 rows. Prismatic and cluster crystals of calcium oxalate, laticiferous tubes, tannin and resin cells (tested by $\mathrm{FeCl}_{3} \& \mathrm{I}_{2}$ ) are frequently distributed in the cortical parenchyma. The endodermis is indistinct. The pericycle; is parenchymatous interrupted with groups of lignified fibers (Fig. 2E). The fibers are usually long, with thick lignified straight walls, narrow lumen and pointed apices (Fig. 3D). Vascular tissue; consists of a continuous ring of an outer phloem and an inner xylem showing cambium in between and traversed by medullary rays. The vascular bundle is accompanied by perimedullary phloem. The phloem; consists of soft tissue of sieve tubes, companion cells and thin-walled phloem parenchyma. The medullary rays are uniseriate to biseriate consisting of thin-walled, somewhat radially elongated cells. The cambium; consists of 2-4 rows of rectangular thinwalled meristematic cells. The xylem; is formed of a continuous ring of lignified spiral, pitted and annular vessels (Fig. 2F, 3E); accompanied by wood parenchyma, consists of rectangular cells with pitted lignified walls (Fig. 3J) and wood fibers which are moderate in length with straight thick lignified walls and acute apices (Fig. 3D). The medullary rays are uniseriate to biseriate and composed of subrectangular cells with lignified and pitted walls. The pith; consists of somewhat large rounded thin-walled parenchyma with narrow intercellular spaces. Prismatic and cluster crystals of calcium oxalate, laticiferous tubes, tannin cells (stained blue with $\mathrm{FeCl}_{3}$ solution) and resin cells (stained brown with iodine solution) with brown content are distributed in the tissue of phloem and pith (Fig. 2G).

The powdered young stem: (Fig. 3A-J):

The powdered young stem is green in colour with faint characteristic odour and bitter taste. Microscopically it is characterized by the following features:

A) Fragments of the epidermis, polygonal, axially elongated cells with straight anticlinal walls and covered with smooth cuticle.

B) Unicellular, non-glandular trichomes either short, thin-walled with acute curved apex or mostly long, thick-walled with very narrow lumen, acute apex and covered by smooth cuticle.

C) Numerous clusters and prismatic crystals of calcium oxalate either free or in cells mostly in groups and occur near the veins.

D) Fragments of pericyclic and wood fibers, with acute apices and thick lignified straight walls.

E) Fragments of lignified spiral, pitted and annular xylem vessels.

F) Non-branched laticiferous tubes containing granular contents.

G) Fragments of isodiametric to slightly elongated, thick-walled lignified sclereids with straight to slightly wavy anticlinal walls.

H) Fragments of tannin cells.

I) Resin cells with brown contents.

J) Fragments of wood parenchyma with pitted lignified walls. 


\subsubsection{The leaf: (Fig. $4 \mathrm{~A}, \mathrm{~B}, \mathrm{D}-\mathrm{F})$ :}

A transverse section in the leaf shows a dorsiventral mesophyll with 1-2 rows of palisade cells on the upper side being interrupted at the midrib region by the cortical cells. There is a hypodermal layer frequently abutting the upper epidermis. The midrib is more prominant at the lower side and traversed by a large vascular bundle surrounded by lignified pericyclic fibres.

\subsection{The leaf lamina:}

\section{The epidermises:}

The epidermises of both surfaces are nearly similar in shape (Fig. 4D, E). They are polygonal, nearly isodiametric, with straight anticlinal walls, covered with thick smooth cuticle on the upper surface (Fig. 4D), striated on the lower surface (Fig. 4E). The lower epidermis shows sunken stomata of the anomocytic type (4-6 subsidary cells) which are absent on the upper surface. Trichomes on both surfaces are like those of the stem. Cystolith cells of calcium carbonate are frequently present below the upper epidermis.

\section{The hypodermis:}

The hypodermis consists of 1-2 rows of polygonal, square like parenchyma. Some large rounded cells below the upper epidermis contain a large stalked elongated cystolith of calcium carbonate (Fig. 4F).

\section{The mesophyll:}

The mesophyll (Fig. 4B) is heterogenous, showing a layer of palisade abutting the upper hypodermis and discontinuous in the midrib region. The palisade cells (Fig. 4F) are arranged in 1-2 rows; they are columnar, narrow, cylindrical and thin-walled (Fig. 5H). The spongy tissue is formed of more or less rounded cells containing clusters and prisms of calcium oxalate crystals as well as laticiferous tubes, tannin and resin cells with brown content are scattered in the mesophyll.

\subsection{The leaf midrib: (Fig. 4B):}

The cortical tissue of the midrib consists of 7-10 rows of collenchymatous cells abutting the upper and lower epidermises. The parenchyma region is formed of 12-16 rows, they are rounded thin walled with intercellular space and containing scattered laticiferous tubes, tannin and resin cells with brown content as well as clusters and prisms of calcium oxalate crystals.

The pericycle; is formed of a continuous ring of fibers. The fibers are spindle in shape with lignified thick-walls and acute apices (Fig. 5E).

The vascular tissue; consists of collateral vascular bundle with few groups of perimedullary phloem within the vascular ring. It is composed of a ring of outer phloem and inner xylem surrounding parenchymatous pith. The phloem is formed of polygonal thin-walled cellulosic sieve elements and phloem parenchyma. The xylem vessels are arranged in radial rows, formed of lignified spiral, pitted and annular vessels (Fig. 5F). Wood fibers are lignified moderate in length with wide lumina (Fig. 5E). Wood parenchyma consists of rectangular cells with pitted lignified walls (Fig. 5K).

\subsection{The petiole: (Fig. $4 \mathrm{C}, \mathrm{G})$ :}

A transverse section in the petiole is more or less circular in outline and is nearly similar in structure to the stem branch with absence of sclerenchymatous layer in the cortex.

The powdered leaf: (Fig. 5A-K):

The powdered leaf is dark green in colour with faint characteristic odour and bitter taste. Microscopically it is characterized by the following features:

A) Fragments of the upper epidermis, polygonal cells, with straight anticlinal walls, covered with thick smooth cuticle, showing cystolith of calcium carbonate. 
B) Fragments of the lower epidermis, polygonal cells, with straight anticlinal walls, covered with thick striated cuticle, showing sunken anomocytic stomata.

C) Unicellular, non-glandular trichomes either short, thin-walled with acute curved apex or mostly long, thick-walled with very narrow lumen, acute apex and covered by smooth cuticle.

D) Numerous clusters and prismatic crystals of calcium oxalate either free or in cells mostly in groups near the veins.

E) Numerous fragments of pericyclic and wood fibers, with pointed apices and thick lignified straight walls.

F) Fragments of lignified spiral, pitted and annular xylem vessels.

G) Non-branched laticiferous tubes containing granular contents.

H) Fragments of palisade cells.

I) Fragments of tannin cells.

J) Resin cells with brown content.

K) Fragments of wood parenchyma with pitted lignified walls.

\subsubsection{The fruit: (Fig. 6A, B, D, E):}

A transverse section in the fruit shows outer epidermis followed by wide parenchymatous cortical tissue which is traversed by some collateral vascular bundles. laticiferous tubes, tannin and resin cells as well as clusters and prisms of calcium oxalate crystals are scattered in the cortical tissue. The innermost layer of cortical tissue is sclerenchymatous.

The epidermis consists of polygonal, isodiametric cells with cellulosic anticlinal walls, showing few sunken anomocytic stomata. The trichomes are non-glandular, unicellular either short, thin-walled with acute curved apex or mostly long, thick-walled with narrow lumen, acute apex and covered by smooth cuticle (Fig. 6D).

The cortical tissue consists of wide parenchymatous cells which are traversed by small collateral vascular bundles. laticiferous tubes, tannin and resin cells with brown content, in addition to cells with cluster and prismatic crystals of calcium oxalate are present in the cortical tissue. The innermost layer is formed of sclerenchymatous cells. The sclereids are polygonal, thick-walled lignified cells with different shape and size usually isodiametric to slightly elongated with straight to slightly wavy anticlinal walls (Fig. 6E, 7F).

\section{The fruit stalk: (Fig. 6C):}

A transverse section in the fruit stalk is more or less circular in outline and is nearly similar in structure to the stem branch with absence of sclerenchymatous layer in the cortex.

\section{The powdered fruit: (Fig. 7A-I):}

The powdered fruit is dark greenish-brown in colour with faint characteristic odour and slightly disagreeable taste. Microscopically it is characterized by the following features:

A) Fragments of the epidermis, polygonal, isodiametric cells with straight cellulosic anticlinal walls showing sunken anomocytic stomata.

B) Unicellular, non-glandular trichomes either short, thin-walled with acute curved apex or mostly long, thick-walled with very narrow lumen, acute apex and covered by smooth cuticle.

C) Fragments of xylem vessels of spiral, pitted and annular thickening.

D) Scattered cluster and prismatic crystals of calcium oxalate.

E) Fragments of pericyclic fibers of the fruit stalk which are fusiform with thick lignified walls.

F) Fragments of polygonal to slightly elongated, thick-walled, lignified sclereids.

G) Non-branched laticiferous tubes containing granular contents. 
H) Fragments of tannin cells.

I) Resin cells with brown content.

All the previous descriptions are in agreement with the general characters of family Moraceae (Metcalfe and Chalk 1983; Solereder 1908).

The microscopical measurements of different elements of the organs of Ficus auriculata Lour. in microns are listed in table (1).

Table (1): The microscopical measurements of different elements of Ficus auriculata Lour. in microns.

\begin{tabular}{|c|c|c|c|c|}
\hline Item & Length & Width & Height & Diameter \\
\hline $\begin{array}{l}\text { Young stem: } \\
\text { Epidermis }\end{array}$ & $25-32-49$ & $13-16-23$ & $9-12-16$ & \\
\hline Clusters of Ca oxalate & & & & $16-21-30$ \\
\hline Prisms of Ca oxalate & $29-32-35$ & $25-\underline{26-28}$ & & \\
\hline Pericyclic fibers & $980-1060-1200$ & $13-\overline{18}-30$ & & \\
\hline Wood fibers & $950-1020-1160$ & $11-\overline{17}-28$ & & \\
\hline Sclereids & $25-\underline{32-51}$ & $24-25-27$ & & \\
\hline Xylem vessels & & & & $38-46-79$ \\
\hline Non glandular trichomes & $30-\underline{33}-35,67-69-75$ & & & \\
\hline $\begin{array}{l}\text { Leaf: } \\
\text { Upper epidermis }\end{array}$ & $22-\underline{25-43}$ & $14-19-27$ & $11-12-14$ & \\
\hline Lower epidermis & $19-\overline{21}-42$ & $13-\overline{16}-25$ & $10-\overline{11}-14$ & \\
\hline Stomata & $24-\underline{28}-34$ & $19-\overline{20}-23$ & & \\
\hline Palisade cells & $20-69-180$ & $23-30-42$ & & \\
\hline Clusters of Ca oxalate & & & & $15-19-27$ \\
\hline Prisms of Ca oxalate & $30-\underline{31-33}$ & $23-24-27$ & & \\
\hline Pericyclic fibers & $890-960-1090$ & $10-\underline{16}-23$ & & \\
\hline Wood fibers & $870-\underline{940}-1080$ & $8-\underline{13}-20$ & & \\
\hline Xylem vessels & & & & $34-42-74$ \\
\hline Non glandular trichomes & $28-30-34,61-66-74$ & & & \\
\hline $\begin{array}{l}\text { Fruit: } \\
\text { Epidermis }\end{array}$ & $23-27-35$ & $15-17-27$ & $10-12-15$ & \\
\hline Sclereids & $22-\overline{30}-45$ & $20-\overline{23}-26$ & & \\
\hline Non glandular trichomes & $26-31-37,58-64-73$ & & & \\
\hline Xylem vessels & & & & $30-\underline{39-51}$ \\
\hline Clusters of Ca oxalate & & & & $10-14-22$ \\
\hline Prisms of Ca oxalate & $25-28-32$ & $20-22-26$ & & \\
\hline
\end{tabular}




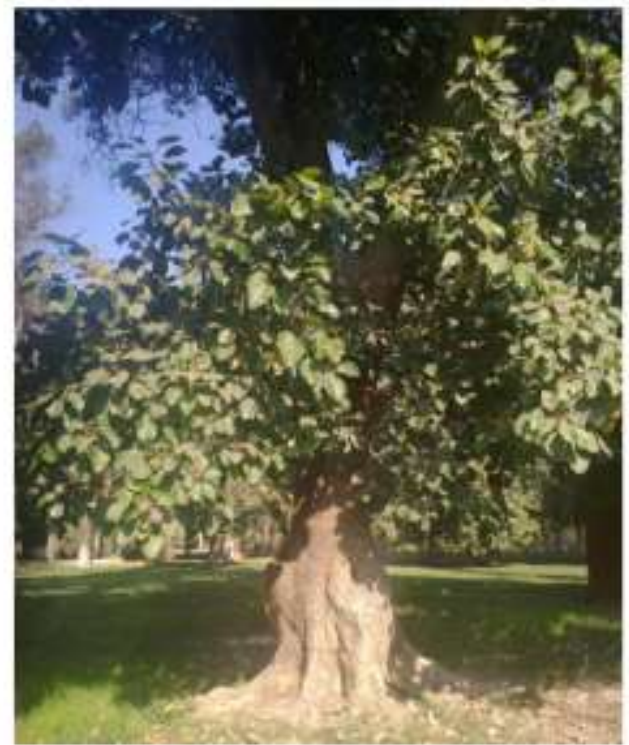

(A) $\mathrm{X}: 0.01$

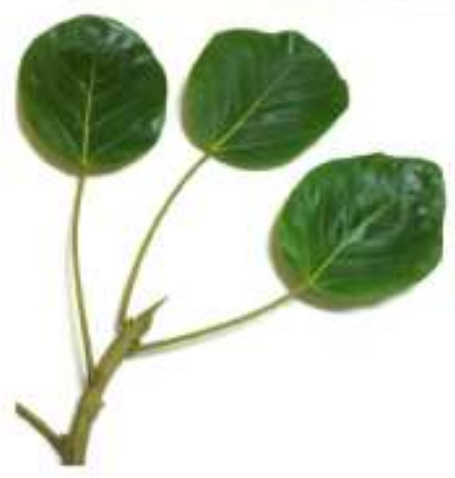

(B) X: 0.3

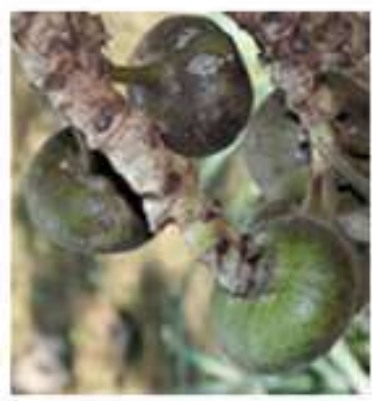

(E) $\mathrm{X}: 0.3$

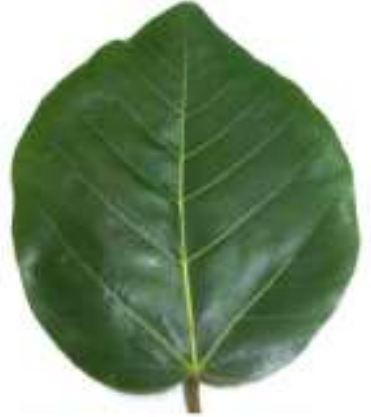

(C) $\mathrm{X}: 0.6$

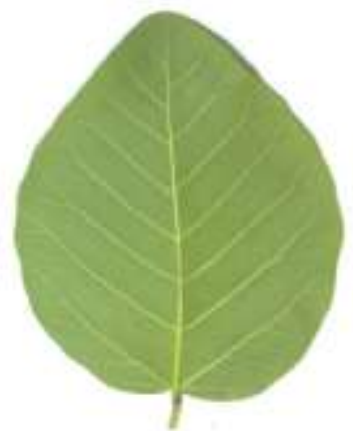

(D) $\mathrm{X}: 0.6$

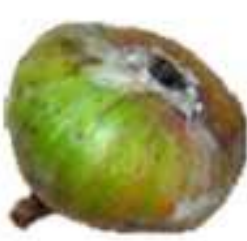

(F) $\mathrm{X}: 0.4$

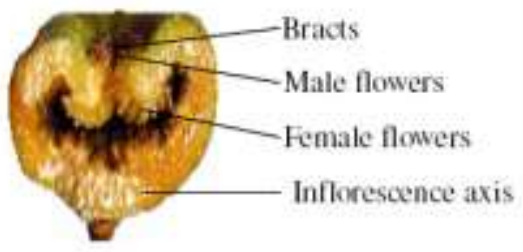

(G) $\mathrm{X}: 0.4$

Fig. (1)

Fig.(1): Macromorphology of Ficus auriculata Lour.
A: Entire tree (X: 0.01)
B: Young stem bearing leaves (X: 0.3)
$\mathrm{C}$ : Leaf from upper side $(\mathrm{X}: 0.6)$
D: Leaf from lower side (X: 0.6)
$\mathrm{E}$ : Branch of fruits (X: 0.3)
F: Entire fruit (X: 0.4)

G: L. cut in fruit (X: 0.4) 


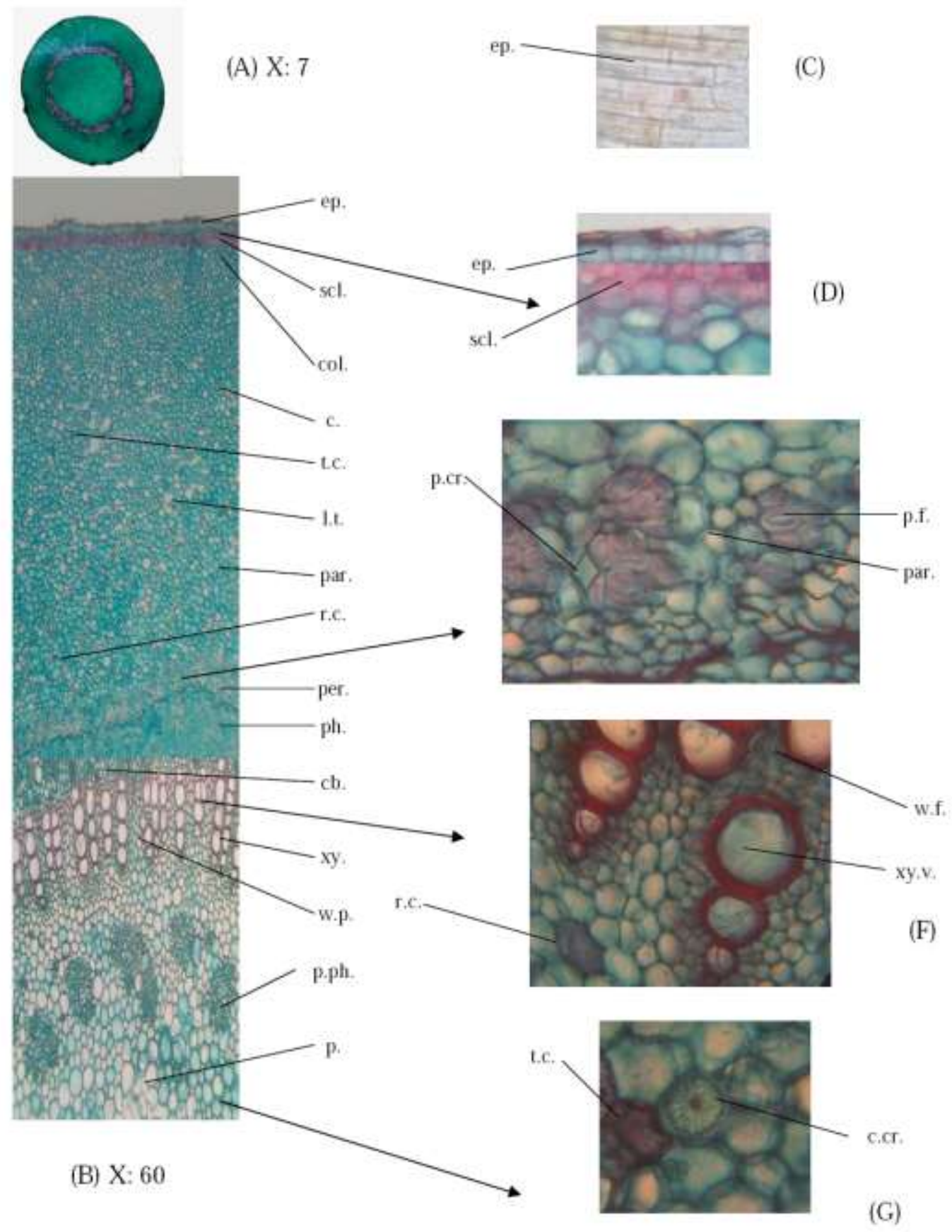

(E)

Fig. (2) A (X: 7), B (X:60), C-G (X: 280)

Fig.(2): Micromorphology of young stem

A: T.S. diagram in young stem $(\mathrm{X}: 7)$

B: T.S. sector in young stem (X: 60)

C: Surface preparation of young stem (X: 280) D, E, F and G: Detailed sector of young stem (X: 280) c., cortex; c.cr., cluster crystal; cb., cambium; col., collenchyma; ep., epidermis; 1.t., laticiferous tube; p., pith; p.cr., prismatic crystal; p.f., pericyclic fiber; p.ph., perimedullary phloem; par., parenchyma; per., pericycle; ph., phloem; r.c., resin cell; scl., sclereids; t.c., tannin cell; w.f., wood fiber; w.p., wood parenchyma; xy., xylem; xy.v., xylem vessel. 
(A)

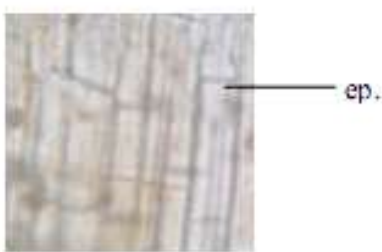

(C)

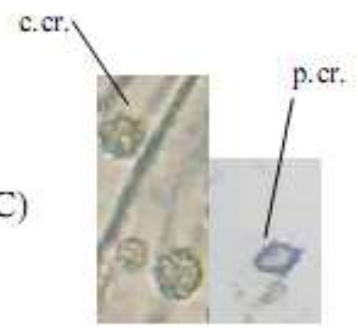

(E)

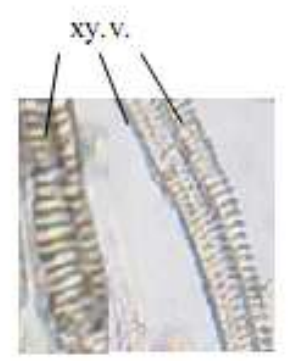

(G)

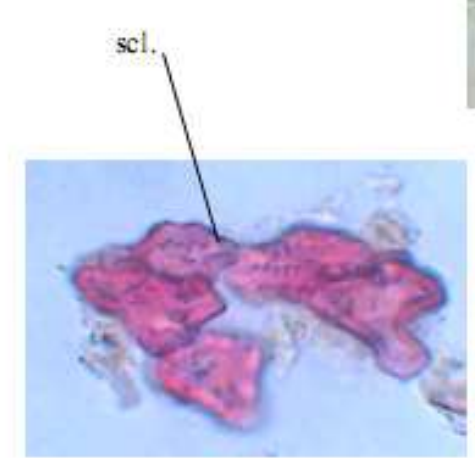

(B)
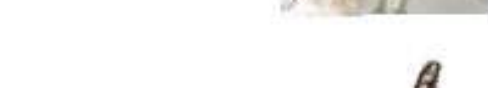

$$
\text { . }
$$

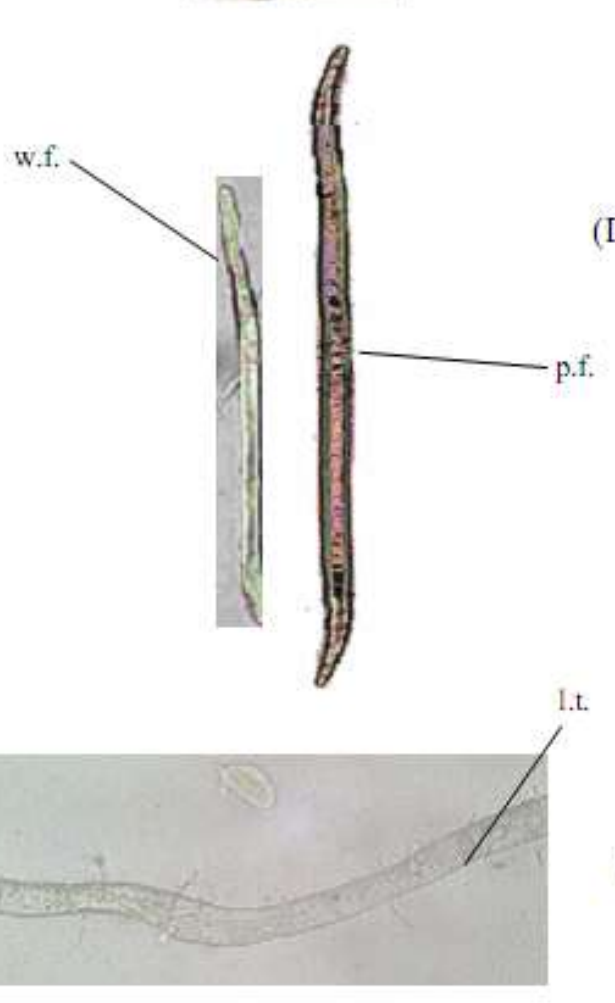

(H)

(F)

(D)

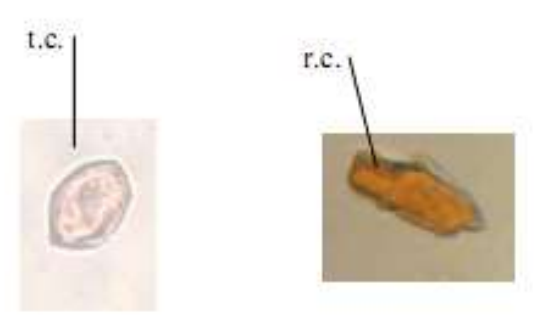

(I)

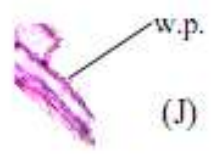

Fig. (3) D (X: 90), other X: 280

Fig.(3): Powdered young stem (X: 280 except D X: 90)

c.cr., cluster crystal; ep., epidermis; 1.t., laticiferous tube; p.cr., prismatic crystal; p.f., pericyclic fiber; r.c., resin cell; scl., sclereids; t.c., tannin cell; tr., trichomes; w.f., wood fiber; w.p., wood parenchyma; xy.v., xylem vessel. 


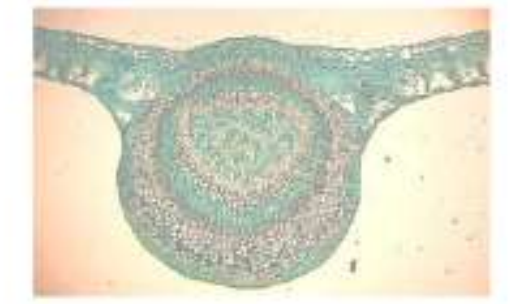

(A) $\mathrm{X}: 8$
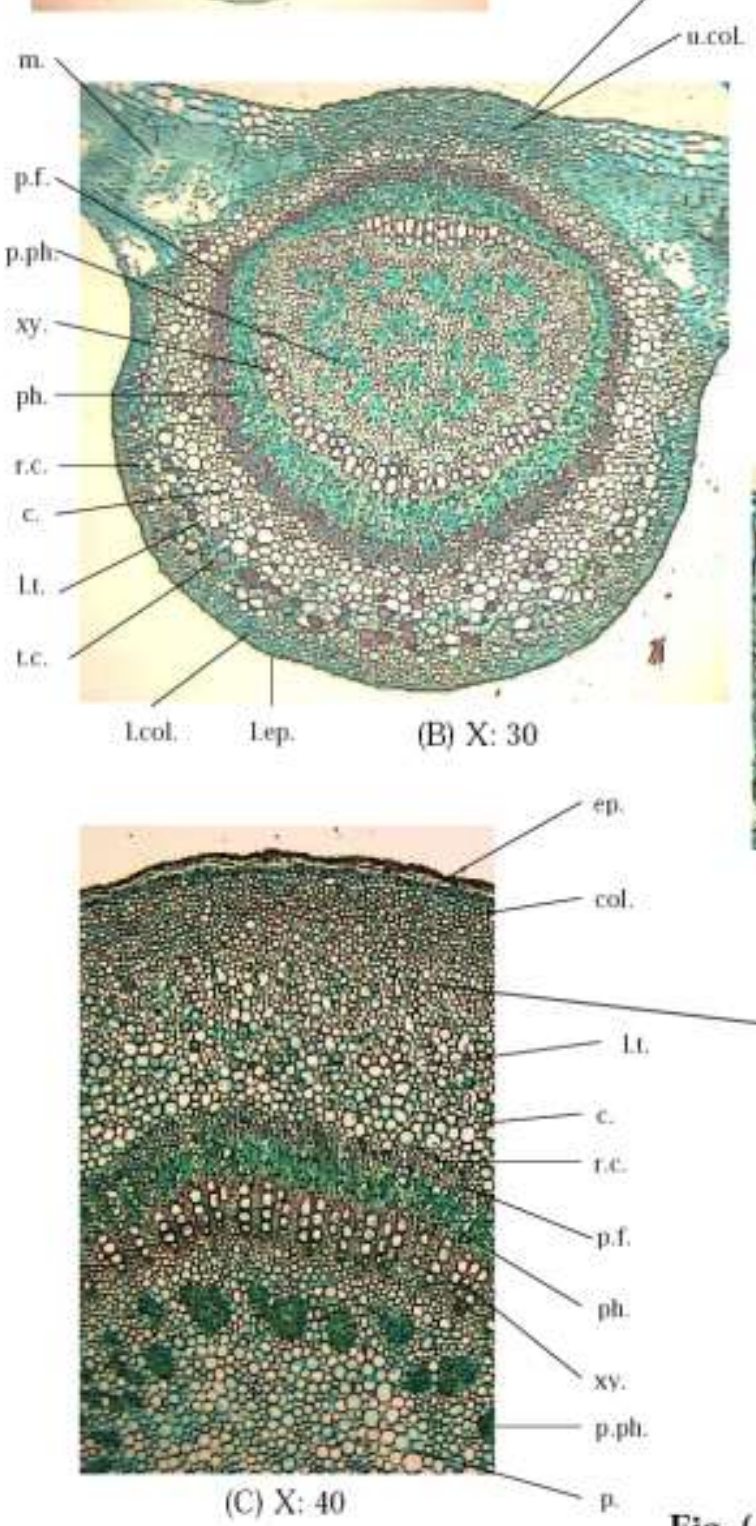

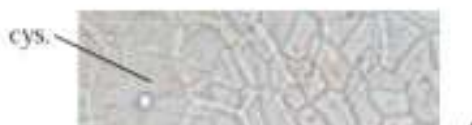

(D) $\mathrm{X}: 280$
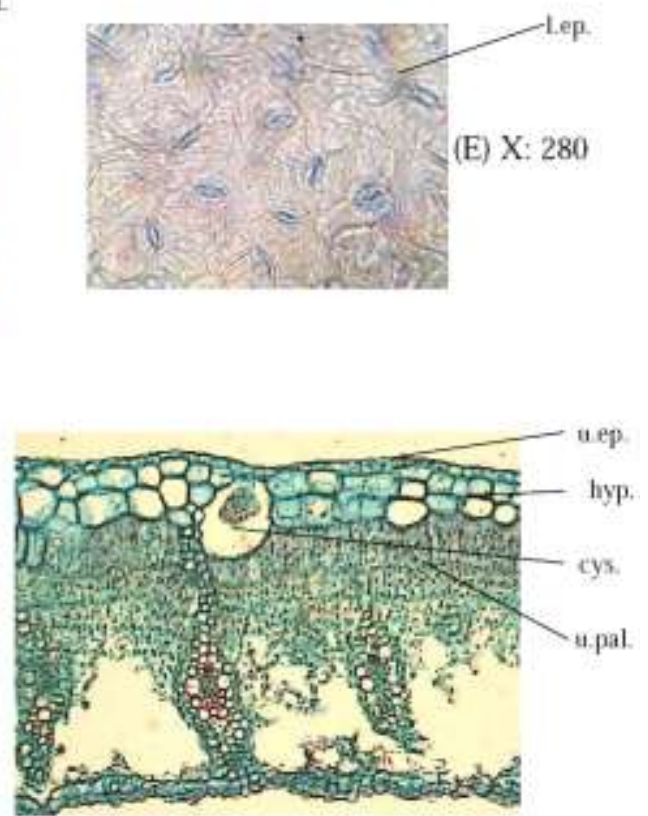

(F) $\mathrm{X}: 70$

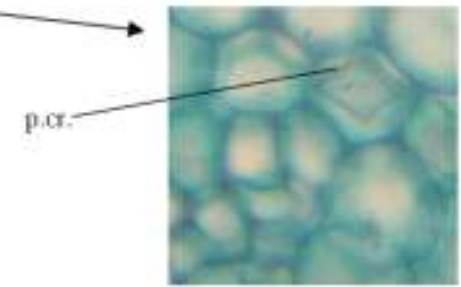

(G) X: 280

Fig. (4)

Fig.(4): Micromorphology of leaf

A: T.S. diagram of leaf $(X: 8)$

B: T.S. sector of leaf midrib (X: 30)

C: T.S. in leaf petiole (X: 40)

D: Surface preparation of upper epidermis (X: 280)

E: Surface preparation of lower epidermis (X: 280)

F: Detailed sector of leaf mesophyll (X: 70)

G: cortex of leaf petiole (X: 280)

c., cortex; col., collenchyma; cys., cystolith; ep., epidermis; hyp., hypodermis; 1.col., lower collenchyma; l.ep., lower epidermis; 1.t., laticiferous tube; m., mesophyll; p., pith; p.cr., prismatic crystal; p.f., pericyclic fiber; p.ph., perimedullary phloem; ph., phloem; r.c., resin cell; t.c., tannin cell; u.col., upper collenchyma; u.ep., upper epidermis; u.pal., upper palisade; xy., xylem. 
(A)
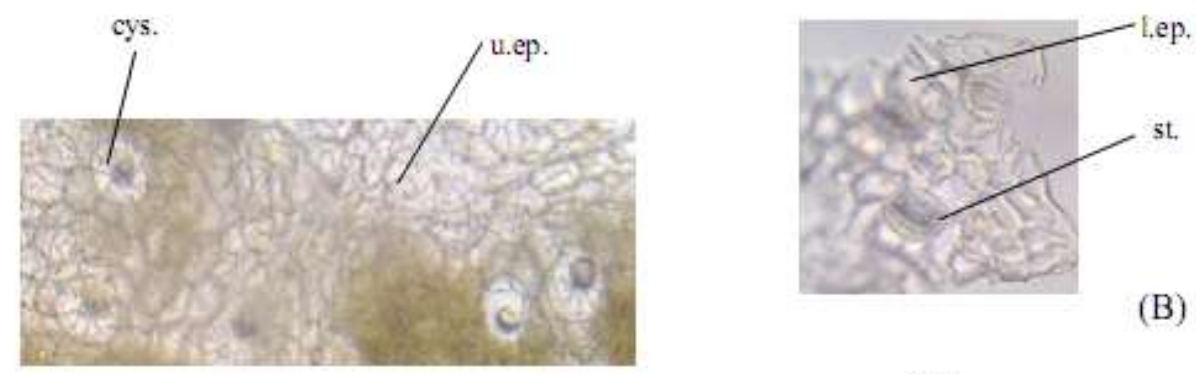

(C)
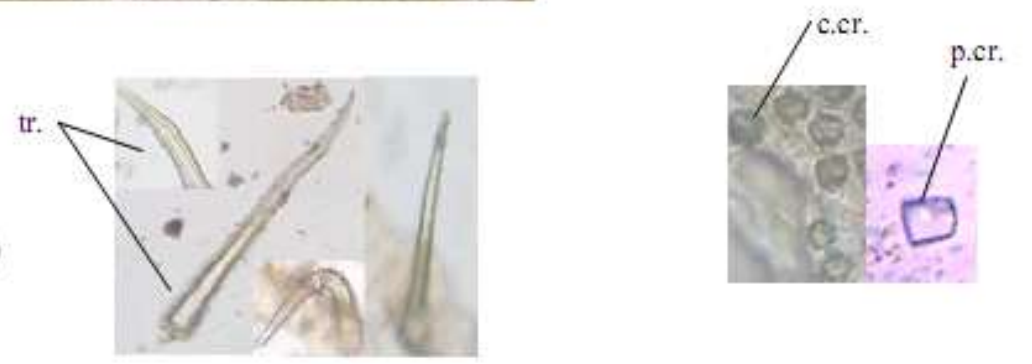

(D)

(E)
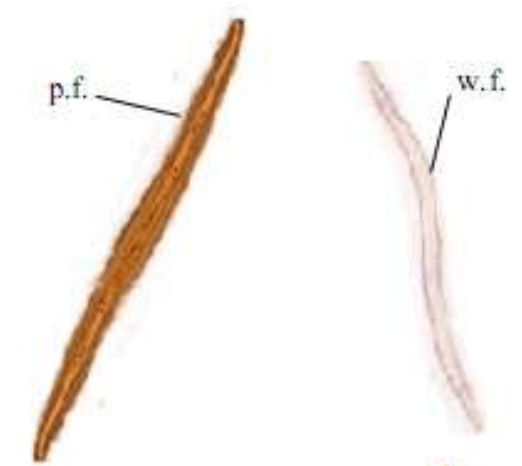

(G)
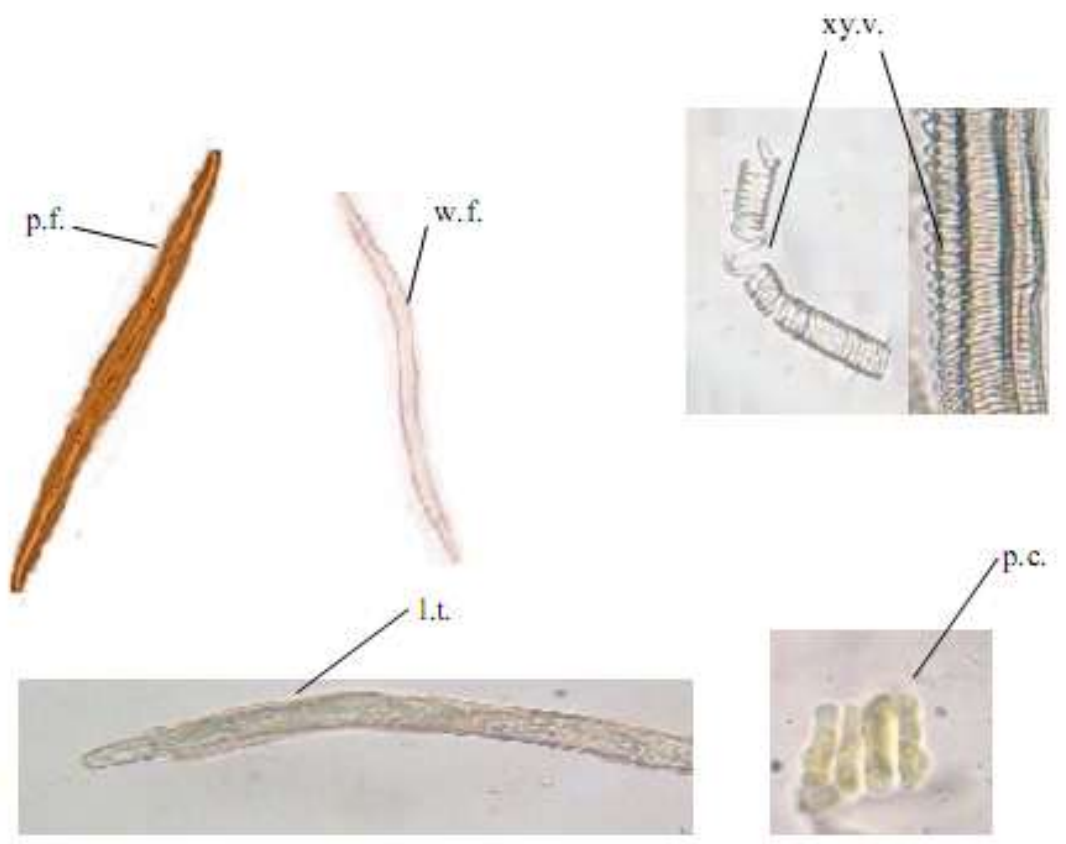

(F)

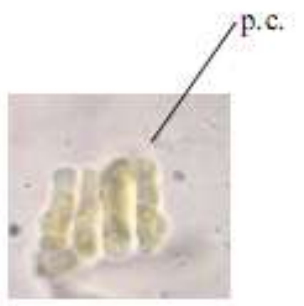

(H)

(I)

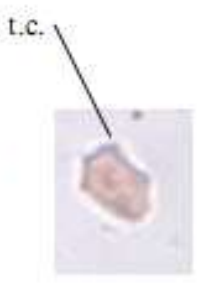

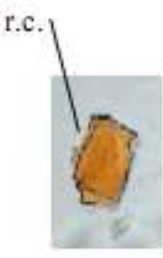

(J)

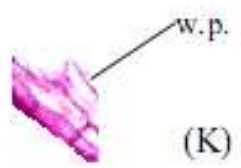

Fig. (5) E (X: 90), other X: 280

Fig.(5): Powdered leaf (X: 280 except E X: 90)

c.cr., cluster crystal; 1.ep., lower epidermis; 1.t., laticiferous tube; p.c., palisade cell; p.cr., prismatic crystal; p.f., pericyclic fiber; r.c., resin cell; st., stomata; t.c., tannin cell; tr., trichomes; u.ep., upper epidermis; w.f., wood fiber; w.p., wood parenchyma; xy.v., xylem vessel. 

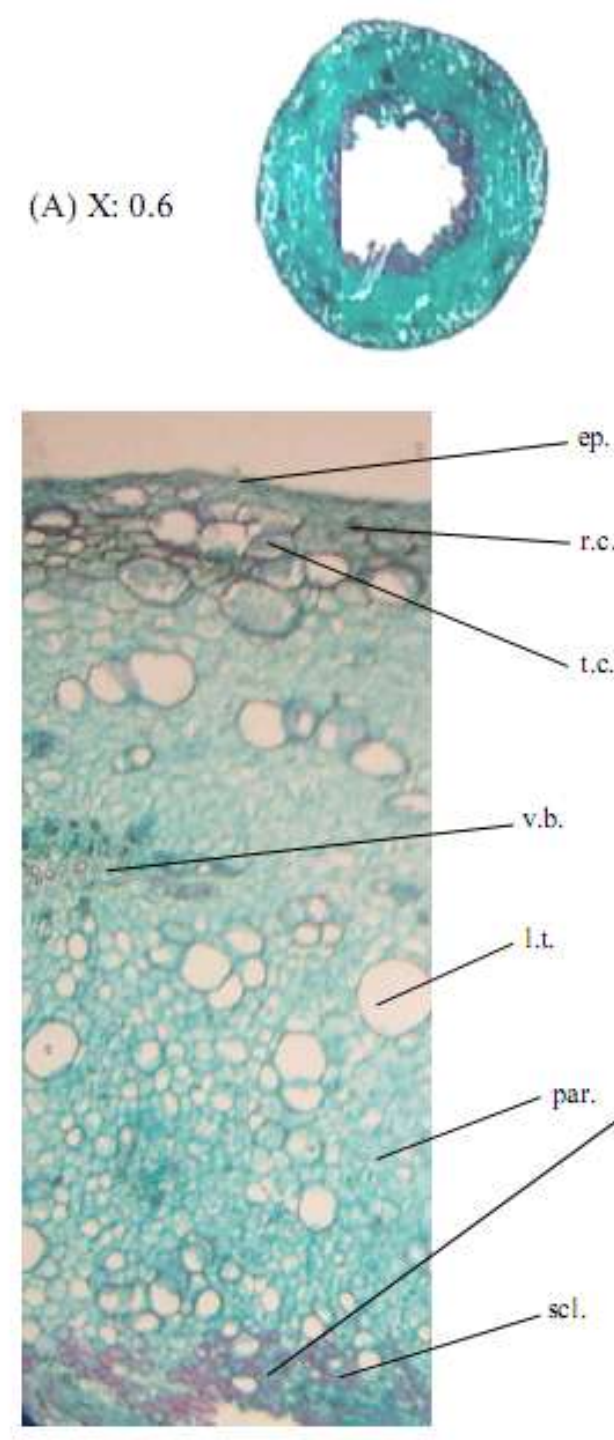

(B) $\mathrm{X}: 70$

(D) $\mathrm{X}: 280$
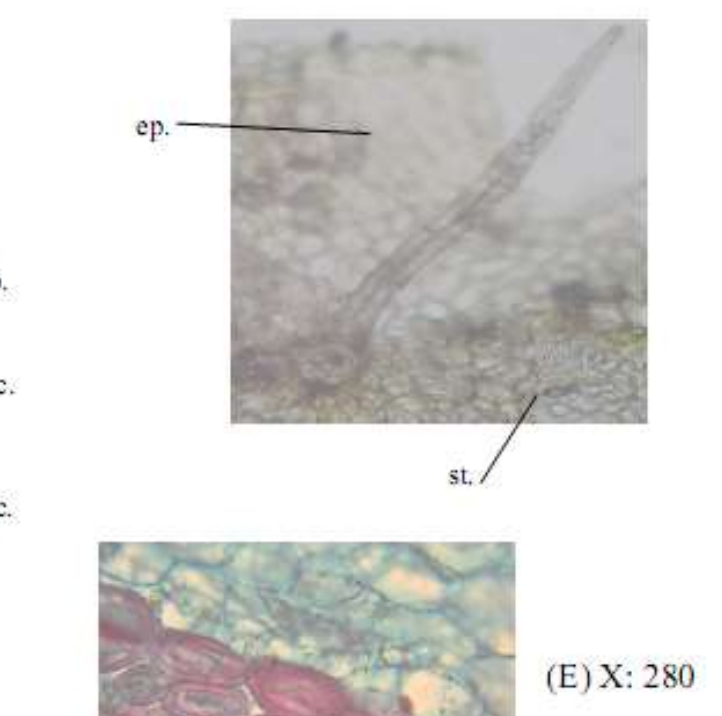

(C) $\mathrm{X}: 60$

Fig. (6)

\section{Fig.(6): Micromorphology of fruit}
A: T.S. diagram of fruit (X: 0.6)
C: T.S. in fruit stalk (X: 60)
B: T.S. sector of fruit (X: 70)
E: Detailed sector of fruit (X: 280)
D: Surface preparation of fruit (X: 280)

c., cortex; col., collenchyma; ep., epidermis; 1.t., laticiferous tube; p., pith; p.f., pericyclic fiber; p.ph., perimedullary phloem; par., parenchyma; ph., phloem; r.c., resin cell; scl., sclereids; st., stomata; t.c., tannin cell; v.b., vascular bundle; xy., xylem. 
(A)

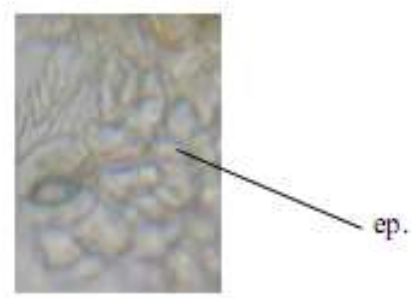

(C)

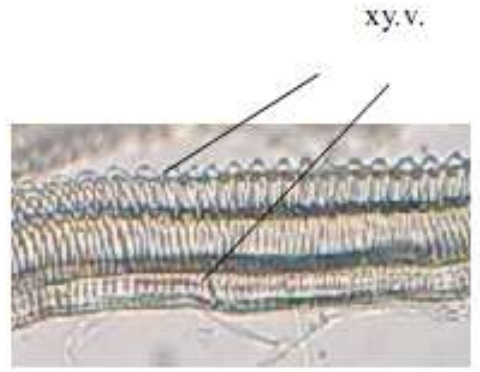

tr.

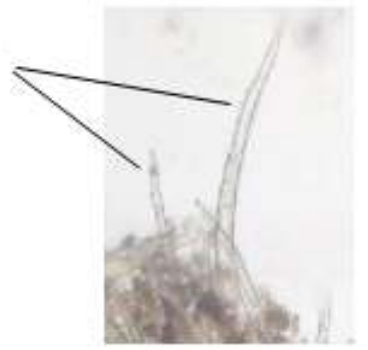

(B)

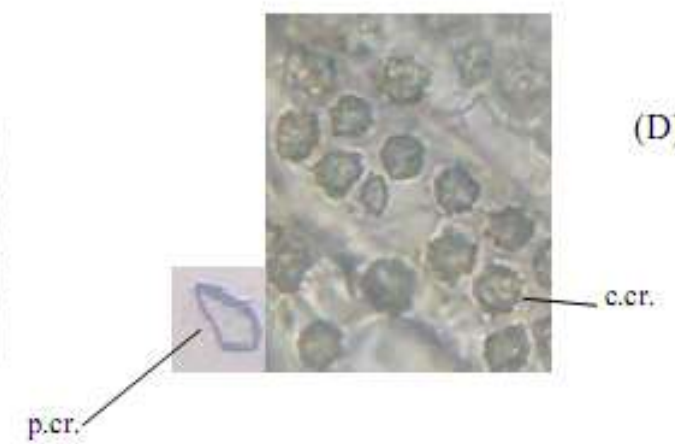

(D)

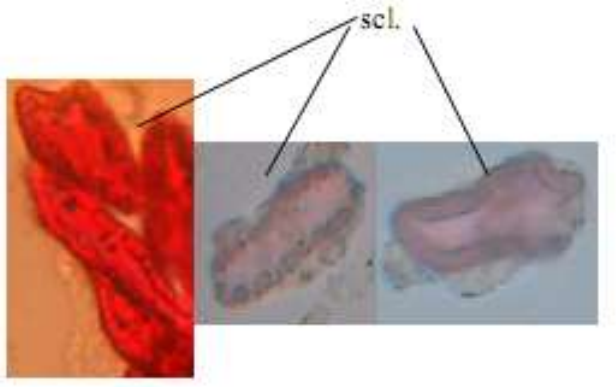

(F)

(E)

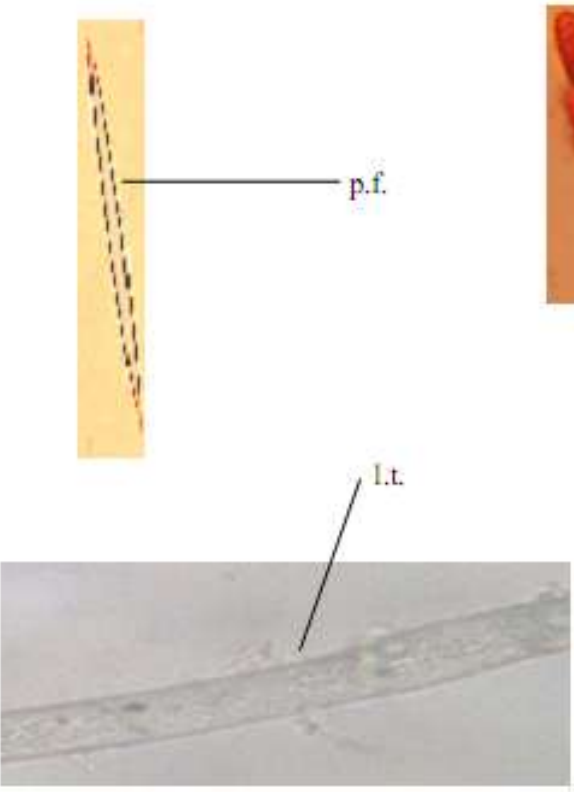

(G)

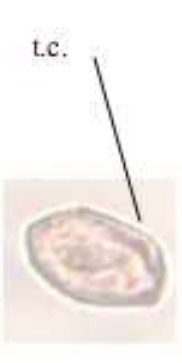

(H)

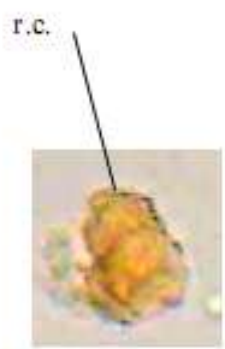

(1)

Fig. (7) E (X: 100), other X: 320

Fig.(7): Powdered fruit (X: 320 except E X: 100)

c.cr., cluster crystal; ep., epidermis; l.t., laticiferous tube; p.cr., prismatic crystal; p.f., pericyclic fiber; r.c., resin cell; scl., sclereids; t.c., tannin cell; tr., trichomes; xy.v., xylem vessel. 


\section{REFERENCES}

Bafor $E \boldsymbol{E}, \boldsymbol{U}$ wumarongie $\boldsymbol{H} \boldsymbol{O}$, Idiake $J \boldsymbol{O}$. (2010): Antipyretic effects of the aqueous, ethyl acetate and hexane leaf extracts of Ficus exasperata (Moraceae) in mice. J. Thermal Biology; 35: 275-9.

Bailey L H. (1958): Manual of cultivated plants. Macmillan Company, New York.; 336-42.

Bhattarai $N$ K. (1993): Folk herbal remedies for diarrhoea and dysentery in Central Nepal. Fitoterapia; 64: 243-50.

Channabasavaraj K P, Badami S, Bhojraj S. (2008): Hepatoprotective and antioxidant activity of methanol extract of Ficus glomerata. J. Nat. Med. 2008; 62: 379-83.

Chen L W, Cheng M J, Peng C F, Chen I S. (2010): Secondary metabolites and antimycobacterial activities from the roots of Ficus nervosa; Chemistry \& Biodiversity; 7: 1814-21.

Chiang Y M, Chang J Y, Kuo C C, Chang C Y, Kuo Y H. (2005): Cytotoxic triterpenes from the aerial roots of Ficus microcarpa. Phytochemistry; 66: 495-501.

El-Fishawy A, Zayed R, Afifi S. (2011): Phytochemical and pharmacological studies of Ficus auriculata Lour. Journal of Natural Products; 4: 184-95.

Jain S P, Puri H S. (1984): Ethnomedicinal plants of Jaunsar-Bawar Hills, Uttar Pradesh, India. Journal of Ethnopharmacology; 12: 213-22.

Johansen D A. (1940): Plant Microtechnique. New York.

Khan N, Sultana S. (2005): Chemomodulatory effect of Ficus racemosa extract against chemically induced renal carcinogenesis and oxidative damage response in wistar rats. Life Sciences; 77: 1194-210.

Kuete V, Ngameni B, Simo C C F, Tankeu R K, Ngadjui B T, Meyer J J M, Lall N, Kuiate J R. (2008): Antimicrobial activity of the crude extracts and compounds from Ficus chlamydocarpa and Ficus cordata (Moraceae). Ethnopharmacology; 120: 17-24.

Llamas K A. (2003): Tropical flowering plants a guide to identification and cultivation. Portland: Cambridge; 276-7.

Mandal S C, Maity T K, Das J, Saba B P, Pal M. (2000): Anti-inflammatory evaluation of Ficus racemosa Linn. leaf extract. Ethnopharmacology; 72: 87-92.

Metcalfe C R, Chalk L. (1983): Anatomy of the Dicotyledons. Clarendon Press, Oxford, U.K; 2: 70-81.

Oliveira A P, Valentao P, Pereira J A, Silva B M, Tavares F, Andrade P B. (2009): Ficus carica L.: Metabolic and biological screening. Food and Chemical Toxicology; 47: 2841-46.

Pandit R, Phadke A, Jagtap A. (2010): Antidiabetic effect of Ficus religiosa extract in streptozotocin-induced diabetic rats. Journal of Ethnopharmacology; 128: 462-6.

Saber A H. (1966): Practical Pharmacognosy with a general study of plant organs. Al shaab printing house; 163.

Sass J E. (1940): Elements of Botanical Microtechnique. New York. 
Solereder H. (1908): Systematic anatomy of the Dicotyledons. Clarendon Press, Oxford, U.K; 2: 1056-63.

Subramaniam G, Ang H, Ng S, Bus D, Butler S. (2009): A benzopyrroloisoquinoline alkaloid from Ficus fistulosa. Phytochemistry Letters; 2: 88-90.

Ventakamaran K. (1972): Wood phenolics in the chemotaxonomy of the Moraceae. Phytochemistry; 11:1571-86.

Verma A R, Vijayakumar M, Rao C V, Mathela C S. (2010): In vitro and in vivo antioxidant properties and DNA damage protective activity of green fruit of Ficus glomerata. Food and Chemical Toxicology; 48: 704-9.

Zhekun S K Z, Gilbert M G. (2003): Flora of China. 5th ed. Beijing and Missouri; 21-73.

$$
\begin{aligned}
& \text { دراسة عقاقيرية لنبات فيكس أوريكيولاتا لور (عائلة توتية) الأى يزرع في مصر } \\
& \text { 'أحلام الفيشاوى - بو براوية زايد- "شثريف عفيفى }
\end{aligned}
$$

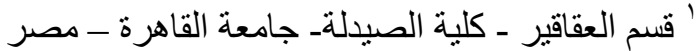

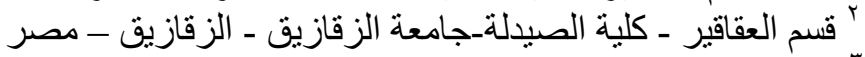

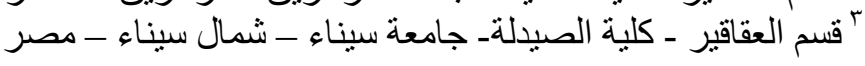

$$
\begin{aligned}
& \text { أجريت في هذا البحث در اسة عيانية و مجهرية لأور اق و ساق و ثمرة نبات فيكس أوريكيو لاتا لور (عائلة توتية) } \\
& \text { التي يمكن أن تساعد في التعرف على النبات في حالته الصحيحة أو مسحوقا. }
\end{aligned}
$$

